\title{
Said the Prophet of God: Hadith Commentary Across a Millennium
}

Joel Blecher

Oakland: University of California Press, 2018, XIV+272 sayfa

ISBN 9780520295940

Hadis şerhçiliği konusunu ciddi olarak ele alan ilk Batılı çalışma sayılabilecek Said the Prophet of God, sosyal tarihi entelektüel tarih ile harmanlama teşebbüsüyle öne çıkar. Yazara göre şerh, himaye sahiplerinin gözüne girmek ve sosyal prestij basamaklarını tırmanmak gibi sonuçlar doğuran ama aynı zamanda gözetilmesi gereken belirli bir âdabı, yorum ve yazım tekniği olan bir faaliyettir ve bu iki yönden biri diğerine indirgenemez. Biraz basitleştirerek ifade edilecek olursa, șerh dünyevî olduğu kadar dinî/ilmî yönlere de sahip bir faaliyet olarak ele alınmalıdır.

Hemen her Batılı çalışma gibi belirli bir paradigmanın içinden konuşan eser, son zamanlardaki İslâmiyat çalışmalarında etkisi gözlemlenen sosyolog Pierre Bourdieu’nün "sosyal pratik" ve "sosyal sermaye" anlayışını sığ ve indirgemeci bulurken, bunun yerine Alasdair MacIntyre ve Talal Asad'in analizlerine seçmeci bir tarzda yaslanmaktadır (s. 17, 88-89, 208). Yazarın tenkitlerinin, Bourdieu’nün fikirlerinin bütüncül bir gözle incelenmesine dayanıp dayanmadığı sorusunu bu alanın ilgililerine bırakmak durumundayız. Fakat her hâlükârda yazar, şerhi dünyevî ilişkilerin şekillendirdiği bir faaliyet olarak görmek ile yalnızca edebî/entelektüel bir gelenek olarak görmek arasında bir denge kurmaya çalışmaktadır.

Kitap, isabetli olarak hadis şerhinin gelişimini üç coğrafya (Endülüs, Memlük dönemi Şam ve Kahire’si, Hint alt kıtası) üzerinden takip etmektedir. Tarihsel kronoloji ile de uyumlu olan bu tasnif kitabın ana bölümlerini 
oluşturmuştur. Hudeybiye Antlaşması'nın yazımı ve tâzir cezasının üst limiti ile ilgili hadislerin şerhini örneklem olarak alan yazar, adı geçen bölgelerdeki şerh faaliyetinin belirgin özelliklerine ve bazı meselelerine değinmektedir. Meselâ Ebü'l-Velîd el-Bâcînin (ö. 474/1081) bir hadis șerhi sebebiyle mâruz kaldığ nımlarına/etkileşimlerine ışık tutmaktadır (s. 21-29).

Kitapta en geniş bölüm, bekleneceği üzere, Memlük dönemi hadis şerhine ayrılmıştır (s. 47-139). İbn Hacer'in (ö. 852/1449) Fethu'l-bârî̀sini merkeze alan yazar, şerh yazım süreci, sultanların huzurunda gerçekleşen ilim meclisleri, ulemâ arasındaki rekabet, intihal, isnadın ve fikıh bilgisinin önemi ve Arap olmayan ulemânın durumu gibi konuları ele alır. Fethu'l-bârî̉nin erken ve geç müsveddelerinin karşılaştırılarak İbn Hacer'in eserde uzun telif süresince yaptığı değişikliklerin takip edilmesi, ayrıca bir hadisenin İnbâül-gumr ve Fethu'lbârîdeki anlatımlarının mukayese edilerek biyografi/tarih ve şerh türleri hakkında gözlemler sunulması, kitaptaki metin işçiliği ile ilgili altı çizilmesi gereken yönlerdir (s. 65-79, 92-97). Buhârîye ait el-Câmiu's-sahîh'in bab başlıklarının (terâcim) şerhlerdeki yerini de inceleyen yazar, terâcim şerhinin bir taraftan şârihlerin taşıması gereken vasıfları ağırlaştırdığını, diğer taraftan ise yorum imkânlarını genişlettiğini vurgular ve bunu bir kitabın eriştiği üstün konumun (yazarın ifadesiyle kanonizasyon) paradokslarından biri olarak takdim eder (s. 111-28). Ayrıca Memlükler döneminde Fethu'l-bârî ve Umdetül-kārî gibi hacimli şerhlerin yanında Süyûtînnin (ö. 911/1505) et-Tevşîh'i gibi pratik kullanımı önceleyen muhtasar şerhlerin de bulunduğuna dikkat çeker (s. 129-39).

Hint alt kıtasına ayrılan üçüncü bölümde kısa bir tarihçe verildikten sonra şârihlerin himayesi, Ehl-i Hadîs ve Diyûbend grupları arasındaki rekabet, kurucu figürler Sıddîk Hasan Han (ö. 1890) ve Keşmîrînin (ö. 1933) mukayesesi, Arapça, İngilizce, Urduca şerhler ve muhatapları ele alınır (s. 141-83). Geniş konu yelpazesi yüzünden zaman zaman dağınık bir görünüm arzeden bölüm, hadis şerhinin XX. yüzyılda belki de en aktif biçimde cereyan ettiği coğrafya hakkında genel bir tablo sunmaktadır.

Kitap, hadis şerhinin bazı militan gruplar elindeki güncel (su)istimalini ele alan bir hâtime ile son bulur (s. 184-96).

Hadis şerhleriyle ilgili modern literatürdeki boşluğu doldurmayı hedefleyen eser, oldukça uzun bir dönemi inceleme konusu yaparak literatürdeki dönüşümleri ve bunun diğer toplumsal aktörlerle irtibatını gözlemlemeye çalş̧ı. Şerhi, çoğu kişinin ilk anda düşündügü gibi masa başında gerçekleşen ve etraftan görece yalıtılmış, kişisel bir faaliyet olarak ele almak yerine, bir meclis/ ders esnasındaki canlı müzakerelerin kayda geçirilmiş hali olarak görmesi ve 
onu muhatap kitleyle etkileşim içinde ortaya çımış bir ürün olarak ele alması, kitabın alana yaptığı en orijinal katkıdır. İslâm tarihindeki pek çok şerhin bir metnin okutulmasına dayanan dersler sonucunda ortaya çımış olması, hatta henüz kitap formuna bürünmemiş hadis şerhlerinin mevcudiyeti, kitapta benimsenen yaklaşımı teyit etmektedir. Nitekim yazar, Şam ve Haydarâbâd'da yaptığ 1 "şerh meclisi gözlemleri" ile çalışmasına somut, anlaşılır ve ikna edici veriler temin ederken, hadis şerhinin günümüz dünyasındaki -ve belki de geçmişteki- mahiyetine dair de fikir vermektedir. Urduca kaynaklara başvurabilmiş olması, Hint alt kıtası şerhlerini analizinde yazara büyük katkı sağlamıştır. Eserde görsel unsurlar da başarılı bir şekilde kullanılmıştır.

Kitabın bazı bilgi ve yorum yanlışlarına işaret etmeden önce yapısal bir problemine değinmek gerekir. Çalışmanın omurgasını oluşturan doktora tezi problem merkezli yazılmışken kitaplaşma sürecinde -muhtemelen genel okuyucu dikkate alınarak- coğrafya ve kronoloji merkezli bir tasnif benimsenmiştir. Bu da yazarın şerh yazım kültürüne dair işaret ettiği küçük ama önemli noktaların ya kitap içinde dağınık halde bulunmasına ya da dipnotlara çekilmesine yol açmıştır. Sarfedildiği anlaşılan bütün editöryal gayrete rağmen gerek bir bölümün kendi içinde (meselâ dokuzuncu bölüm), gerekse bölümler arasında uyumlu bir akıştan bahsetmek zordur. Çalışmanın belirli bölümlerinin kitaplaşma sürecinden önce makale, tebliğ vb. şekillerde ortaya konulmuş olmasının kitaptaki bütünlüğe etki edip etmediği bu bağlamda tartışılabilir.

Hadis şerhinin toplumsal uzanımlarını mahirane bir şekilde gösteren kitap, şerh literatürünün kendisi söz konusu olduğunda aynı bilgi ve analiz düzeyini yakalayamamaktadır. Yazarın birinci bölümde Endülüs şerhçiliğinin bazı temel meseleleriyle yetinerek hadis şerhini kapsamlı bir biçimde incelemeyi amaçlamadığını söylemesi (s. 45), kitabın diğer bölümleri için de akılda tutulması gereken bir noktadır. Așağıda, şerh literatürüyle ilgili olarak kitabın ilk bakışta dikkati çeken eksik veya hatalı yönlerine işaret edilmiştir.

Yazar, muhtelif yerlerde adını andığı Ebû Süleyman el-Hattâbînin (ö. 388/998) şerhlerine doğrudan müracaat etmek yerine sonraki âlimlerin ve Ignaz Goldziher ile Vardit Tokatly gibi araştırmacıların nakilleriyle yetinmiş ve onların bazı yanlış tespitlerini tekrarlamıştır. Meselâ -ihtimalli bir dille söylenmiş olsa da- Hattâbî döneminde Ebû Dâvûd'un es-Sünen'inin Buhârînin el-Câmiu's-sahîh'inden daha yüksek bir itibara sahip olduğu iddiası sağlam bir dayanaktan yoksundur (s. 202). Hattâbînin her iki eser hakkında yazdığ1 şerhlerin yalnızca önsözleri dahi ciddi bir gözle okunsa, el-Câmiu's-sahîh'in -büyük ölçüde câmi' türünde olması sebebiyle- şerhedilmesi çok daha zor bir eser olarak görüldüğü anlaşllabilir. Benzer şekilde, kitapta terâcim hakkındaki meşhur görüşüne yer verilen Bâcînin (s. 27, 117) doğrudan kendi 
metnine atıf yapılması beklenirdi. ${ }^{1}$ Endülüslü İbn Battâl (ö. 449/1057), şerhinin sayısız yerinde Zâhirîler'in görüşlerini eleştirmişken, kitapta neye binaen İbn Battâl' in zâhirî görüşleri zikretmediğinin söylendiği anlaşılamamaktadır (s. 33). ${ }^{2}$ 210. sayfada atıf yapılan el-Muhtasarün-nasîh, bazı küçük açıklamalar içerse de Mühelleb b. Ebû Sufre'nin (ö. 435/1044) Buhârî̉nin el-Câmiu's-sahîh'i üzerine yazdığı bilinen șerh olmayıp daha ziyade bir ihtisar ve tehzip çalışmasıdır. İbn Battâl'in Mühelleb'den naklettiği izahların büyük çoğunluğunun el-Muhtasar'da bulunmaması da eserin Blecher tarafından zannedildiği gibi Mühelleb'in șerhi olmadığını, müellifin el-Câmiu's-sahîh'i șerhettiği başka bir eserinin bulunduğunu gösterir. Endülüslü şârihlerin el-Câmiu's-sahîh'in bab başlıkları karşısındaki tutumları ile ilgili kitapta dile getirilen kanaat aşırı bir genelleme içermektedir (s. 112).

Eserde birtakım yazım/okuma yanlışları da bulunur. Așağıda ilk olarak kitaptaki hatalı ibare verilmiş, iki noktadan sonra ise ibarenin doğru şekli belirtilmiştir: Maratayn: marratayn (s. 75), al-Kushmihānī: al-Kushmīhanī (s. 76, 226), Ibn Taghrībīrdī: Ibn Taghrībardī [İngilizce literatüre göre Taghrïbirdī] (s. 85), taṣbìh: tasbīh (s. 135), Malak al-Muhaddithīn: Malik al-Muhaddithīn (s. 144), bahath wa-hāl: bahth wa-hall (s. 178), al-Mu'allim: al-Mu'lim (s. 203), min al-Afhām: min al-ibhām (s. 225), mukhtari': mukhtara '(s. 226), alṢafāqisī: al-Ṣafāqusī (s. 228), al-Ḥawaynī: al-Ḥuwaynī (s. 233). Ayrıca kitapta değiş̧ik münasebetlerle değinilen Suriyeli âlimin adı Amerikan kütüphane kayıtlarıyla da uyumlu olarak "Na'īm al-'Irqsūsī” şeklinde yazılmışsa da, yaygın Arapça telaffuzu esas alınarak "al-"Araqsūsī" şeklinde zabtedilseydi bu daha isabetli bir tercih olurdu.

\section{Bibliyografya}

Bâcî, et-Ta 'dîl ve't-tecrîh li-men harrece lehü'l-Buhârî fi'l-Câmii's-sahîh, nşr. Ebû Lübâbe Hüseyin, 2. bs., I-III, Tunus: Dârü'l-garbi'l-İslâmî, 1431/2010.

İbn Battâl el-Kurtubî, Şerhu Sahîhil-Buhârî, nşr. Ebû Temîm Yâsir b. İbrâhim, I-XI, 2. bs., Riyad: Mektebetürr-Rüşd, 1423/2003.

Mustafa Macit Karagözoğlu, Dr.Öğr. Üyesi Marmara Üniversitesi İlâhiyat Fakültesi

ORCID 0000-0002-6950-3445 DOI 10.26570/isad.461150

1 İlgili görüş için bk. Bâcî, et-Ta'dîl ve’t-tecrîh, I, 310-11.

2 İbn Battâl'in zâhirî görüşleri zikrettiği veya eleştirdiği yerlere örnek olarak bk. Şerhu Sahîhil-Buhârî, I, 90, 244, 414, 421; II, 86, 93, 137, 294, 414, 507; III, 78, 81, 217, 419; IV, 87, 222, 374, 478; V, 412, 452. 